\title{
Puasa pada Wanita Hamil dan Menyusui
}

\author{
Nasrudin Andi Mappaware', Erlin Syahril'², Ida Royani ${ }^{3}$, Aryanti Bamahry ${ }^{4}$, Asrini \\ Safitri $^{5}$, Nesyana Nurmadila ${ }^{6}$, M. Hamsah ${ }^{7}$, Mona Nulanda ${ }^{8}$, Muhammad Mursyid ${ }^{* *}$ \\ ${ }^{1}$ Fakultas Kedokteran /RS "Ibnu Sina” YW UMI/Bagian Obstetri dan Ginekologi/ Bioetika, \\ Universitas Muslim Indonesia \\ ${ }^{2}$ Fakultas Kedokteran/RS “Ibnu Sina” YW UMI/Bagian Radiologi/Universitas Muslim Indonesia \\ ${ }^{3,6}$ Fakultas Kedokteran/Bagian Ilmu Gizi, Universitas Muslim Indonesia \\ ${ }^{4,5}$ Fakultas Kedokteran/RS “Ibnu Sina” YW UMI/Bagian Gizi Klinik/Universitas Muslim Indonesia \\ ${ }^{7,8}$ Fakultas Kedokteran/Bagian Obstetri dan Ginekologi/Universitas Muslim Indonesia \\ ${ }^{9}$ Fakultas Kedokteran/RS “Ibnu Sina” YW UMI/Bioetika, Universitas Muslim Indonesia \\ *Email Korespondensi: mursyidmuhammad70@yahoo.co.id Telp: 085299155064
}

\begin{abstract}
ABSTRAK
Berpuasa salah satu ibadah yang identik dengan berpantang, terutama untuk berniat, berucap, dan atau melakukan perbuatan yang merupakan pantangan demi mencapai kesempurnaan akhlak, dimana sifat-sifat Allah menjadi terpresentasikan dalam diri manusia. Kehamilan merupakan kondisi khusus yang hanya dihadapi oleh perempuan dan menjadi ujian yang sangat menegangkan bagi seorang perempuan. Banyak perubahan yang terjadi selama kehamilan berlangsung, baik dari psikis maupun fisik. Dalam Islam, perempuan yang tidak diharuskan berpuasa adalah perempuan hamil, mereka yang menyusui, mereka yang haid, dan para perempuan yang berada dalam masa nifas. Periode aman berpuasa bagi wanita hamil pada trisemester 1 dan 2 (di 4-6 bulan). Zat-zat yang diperlukan pada ibu hamil adalah protein, karbohidrat, zat lemak, mineral atau bermacam-macam garam; terutama kalsium, fosfor, dan zat besi (Fe); vitamin dan air. Kekurangan nutrisi pada ibu hamil dan menyusui dapat menyebabkan berbagai gangguan kesehatan seperti anemia, abortus pada ibu hamil, partus prematurus, inertia uteri, perdarahan pasca persalinan, sepsis puerperalis, dan lain-lain, sedangkan makan berlebihan pada ibu hamil dianggap untuk 2 orang, ibu dan janin, dapat menyebabkan komplikasi seperti gemuk, pre-eklamsia, janin besar, dan sebagainya. Puasa pada ibu hamil dan menyusui tergantung pada kesehatannya saat itu serta ada izin dan pengawasan dari dokter. Maka dari itu hukum islam yang mengatur akan hal tersebut tidak mewajibkan seorang ibu hamil dan menyusui untuk berpuasa dan meng-qadha dengan berpuasa dihari lain ataupun membayar fidyah.
\end{abstract}

Kata kunci: Puasa; wanita; hamil; menyusui

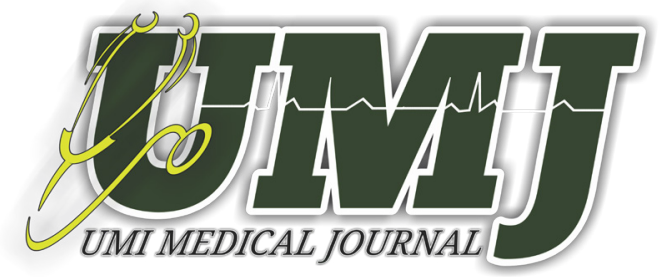

Article history:

Received: 1 May 2020

Accepted: 23 June 2020 Publish Online: 30 June 2020

Published By :

Fakultas Kedokteran

Universitas Muslim Indonesia

Phone:

+6282293330302
Address:

Jl. Urip Sumoharjo Km. 5 (Kampus II UMI)

Makassar, Sulawesi Selatan.

Email:

medicaljournal@umi.ac.id 


\begin{abstract}
Fasting is one of worship which is identical with abstinence, especially to intend, say, and or do acts which are taboo in order to achieve moral perfection, in which the attributes of God become represented in human beings. Pregnancy is a special condition faced only by women and is a very stressful test for a woman. Many changes occur during pregnancy, both psychologically and physically. In Islam, women who are not required to fast are pregnant women, those who breastfeed, those who menstruate, and women who are in childbirth. Safe fasting period for pregnant women in trimesters 1 and 2 (at 4-6 months). Substances required in pregnant women are protein, carbohydrates, fats, minerals or various salts; especially calcium, phosphorus, and iron (Fe); vitamins and water. Nutritional deficiencies in pregnant and lactating women can cause various health problems such as anemia, abortion in pregnant women, parturition prematurus, uterine inertia, postpartum hemorrhage, puerperal sepsis, etc., while overeating in pregnant women is considered for 2 people, mothers and fetus, can cause complications such as fat, pre-eclampsia, large fetus, and so on. Fasting in pregnant and nursing mothers depends on their health at the time and there is permission and supervision from a doctor. Therefore Islamic law that regulates it does not require a pregnant and lactating mother to fast and qadha by fasting on another day or paying fidyah.
\end{abstract}

Keywords: Fasting; woman; pregnant; breastfeeding

\title{
PENDAHULUAN
}

Islam adalah agama samawi terakhir yang diwahyukan Allah Swt. kepada utusan-Nya, Muhammad Saw. untuk disampaikan kepada seluruh umat manusia di dunia. Agama Islam bersifat universal dan menjadi rahmat bagi seluruh alam (rahmatan li al-'alamm). Islam tidak hanya mengatur hubungan manusia dengan Tuhannya dan kedudukan manusia di hadapan Tuhan, tetapi juga memberikan tuntunan bagaimana manusia berhubungan dengan sesamanya, dan bagaimana kedudukan manusia di tengah alam semesta ini. (QS. Al-Imran : 112) yang artinya: "Mereka diliputi kehinaan di mana saja mereka berada, kecuali jika mereka berpegang kepada tali (agama) Allah dan tali (perjanjian) dengan manusia, dan mereka kembali mendapat kemurkaan dari Allah dan mereka diliputi kerendahan. yang demikian itu karena mereka kafir kepada ayatayat Allah dan membunuh Para Nabi tanpa alasan yang benar. yang demikian itu disebabkan mereka durhaka dan melampaui batas."

Kitab suci agama Islam adalah Alquran yang merupakan firman Allah Swt. yang diwahyukan kepada Nabi Muhammad SAW dengan perantaraan Malaikat Jibril yang merupakan pedoman bagi umat Islam. Dalam Islam selain Alquran terdapat Hadis atau Sunnah yang merupakan sumber ajaran Islam kedua. Hadis adalah perkataan, perbuatan, dan takrir (persetujuan) Nabi Muhammad SAW atas perbuatan yang dilakukan para sahabat. Kehidupan spiritual umat Islam diatur terpadu dalam pelaksanaan ibadah praktis, seperti shalat, puasa, zakat, dan haji. Empat macam kewajiban itu mempunyai hubungan kausal dengan aspek akidah dan muamalah (urusan kemasyarakatan/sosial). ${ }^{1}$ 
Namun, bagaimana hukum puasa bagi wanita yang sedang hamil, merawat, melahirkan dan menyusui. Apakah tetap diwujudkan berpuasa atau tidak, atau haruskah mengqadhanya setelah menerima dan kondisikan telah pulih, atau dibutuhkan membayar fidyah sebagai ganti karena ia tidak berpuasa. Seperti yang telah dipikirkan tentang kondisi fisik seorang wanita dalam perdebatan dan saat-saat yang diberikan memang berbeda-beda. Kondisi yang paling menarik yang berbeda bagi ibu dalam menghadapi saat-saat puasa, terutama di bulan Ramadhan ${ }^{1}$

Berpuasa salah satu ibadah yang identik dengan berpantang, terutama untuk berniat, berucap, dan atau melakukan perbuatan yang merupakan "pantangan". Berpuasa, secara lahiriah, mungkin dapat kita pahami sebagai ikhtiar menjaga diri dari segala perkataan dan tingkah laku yang tidak dibenarkan oleh fitrah kemanusiaan. Jadi, dengan berpuasa sesungguhnya manusia telah membuka jalan menjadi insan kamil yang merupakan konsep kesempurnaan akhlak, dimana sifat-sifat Allah menjadi terpresentasikan dalam diri manusia ${ }^{1}$

Kehamilan merupakan kondisi khusus yang hanya dihadapi oleh perempuan dan menjadi ujian yang sangat menegangkan bagi seorang perempuan. Banyak perubahan yang terjadi selama kehamilan berlangsung, baik dari psikis maupun fisik. Hal itu sangat mempengaruhi semua organ tubuh perempuan hamil yang harus mempersiapkan kekuatan ekstra pada setiap tahapan kehamilan. Ada ungkapan yang mengatakan 'makan untuk dua'. Ini merupakan ungkapan yang biasanya dinyatakan untuk mendorong kesehatan ibu dan anak. 2,3,4

Perempuan Muslim di seluruh dunia hidup dalam keadaan yang berbeda dalam kesehatan khususnya perempuan yang hamil, Islam tidak akan begitu kejam untuk memaksakan berpuasa pada orang-orang yang memiliki kesehatan yang buruk atau gizi buruk. Dalam Islam, perempuan yang tidak diharuskan berpuasa adalah:4 a) Perempuan hamil dalam kelanjutan kehamilannya berbahaya bagi diri dan janinnya, b) Mereka yang menyusui, c) Mereka yang haid, dan d) Para perempuan yang berada dalam nifas.

Beberapa agama dan kepercayaan yang ada di muka bumi ini mengajarkan untuk berpuasa. Mereka bahkan memiliki saat-saat khusus untuk berpuasa, yang biasanya ditetapkan berdasarkan pada perubahan musim, pergerakan matahari dan bulan, atau bahkan tanggal dimana sudah ditetapkan oleh pemuka agamanya masing-masing. Bagi beberapa agama, kegiatan berpuasa ini dipercaya sebagai salah satu media pembersihan diri guna mendekatkan manusia dengan sang pencipta. Karenanya, semua orang, dari berbagai usia, ras, dan jenis kelamin berlomba-lomba untuk tekun menjalankan ibadah puasa. Namun, bagaimana halnya bila seorang perempuan yang sedang hamil pun berkeinginan untuk turut mencapai hidayah Tuhan dengan memenuhi kewajibannya menjalankan ibadah puasa. Kenyataannya adalah bahwa manfaat puasa pada kehamilan bervariasi tergantung dari kondisi tubuhnya masing-masing., ${ }^{4,5}$

Keputusan sebagian perempuan hamil untuk tetap menjalani puasa biasanya didasarkan pada keyakinan dan agamanya masing-masing. Pilihan ini pun dikembalikan pada diri masing-masing pribadi, yang tentunya juga mendapatkan dukungan suami dan anggota keluarga yang lain. Bagi para ibu hamil yang berkeinginan untuk mengikuti ritual puasa selama kurun waktu yang lama, misalnya pada bulan ramadhan, bagi yang muslim. Ada baiknya untuk selalu berkonsultasi dengan dokter terkait mengenai kemungkinan untuk berpuasa apabila dikaitkan dengan kondisi fisik, keadaan kandungan dan janin, serta keadaan kesehatan guna menghindari komplikasi yang mungkin timbul. ${ }^{5}$ 
Islam memperbolehkan berpuasa pada perempuan hamil yang sehat dan memungkinkan asupan gizinya terpenuhi walaupun hanya sahur dan berbuka. Hal ini perrnah diujikan oleh Dr Soliman, Yordania di University Hospital pada 42 laki-laki dan 26 wanita, setelah menguji semua fitur dari tes darah ada beberapa perbedaan, namun satu-satu aspek signifikan adalah fakta bahwa laki-laki lebih berat dibandingkan perempuan sebelum puasa dan demikian pula kadar glukosa darah mereka, tetapi semua elemen lain yaitu kortisol, kolesterol, lipoprotein, dan lain-lain tetap sama. Dalam Islam, periode aman berpuasa bagi wanita hamil pada trisemester 1 dan 2 (di 4-6 bulan) dan kemudian tergantung pada kesehatan wanita hamil serta ada izin dan pengawasan dari dokter kandungan. Perempuan hamil dan menyususi harus betul-betul mendapat perhatian susunan dietnya, terutama mengenai jumlah kalori, protein yang berguna untuk pertumbuhan janin dan kesehatan ibu. Kekurangan nutrisi dapat menyebabkan anemia, abortus, partus prematurus, inertia uteri, perdarahan pasca persalinan, sepsis puerperalis, dan lain-lain. Sedangkan makanan berlebihan, karena dianggap untuk 2 orang ibu dan janin, dapat menyebabkan komplikasi seperti gemuk, pre-eklamsi, janin besar, dan sebagainya. ${ }^{2,3,4,6}$

\section{PEMBAHASAN}

\section{Pengaruh Puasa Terhadap Janin}

Masa kehamilan merupakan masa yang penting untuk pertumbuhan dan perkembangan janin. Pada masa ini tidak boleh terjadi gangguan karena dapat menyebabkan gangguan pertumbuhan janin. Gizi ibu yang baik sangat penting untuk pertumbuhan janin. Kekurangan gizi dalam masa ini dapat menyebabkan berat bayi lahir rendah (BBLR). lbu hamil yang mengalami kekurangan gizi maka volume darah menjadi turun, aliran darah ke plasenta turun, plasenta menjadi kecil dan akhirnya suplai makanan ke janin kurang dan dapat mengakibatkan gangguan pertumbuhan janin. ${ }^{7}$

Dalam kondisi hamil, perempuan yang berpuasa sangat ditentukan oleh tingkat gula dalam darah. Untuk diketahui, janin mempunyai persentase konsumsi gula sekitar 6 miligram (mg) setiap kg berat janin permenit. Persentase ini sama dengan tiga kali lipat dari yang dikonsumsi oleh orang dewasa. Hasil penelitian menunjukkan persentase gula dalam wanita hamil mengalami kecenderungan menurun, namun tidak menyebabkan bayi lahir rendah. Ini memerlukan sebuah gambaran singkat mengenai perubahan tubuh selama puasa, yang terjadi dalam tubuh sebagai respon terhadap puasa tergantung pada lama dan asupan energi yang diiperoleh. Dalam keadaan normal, glukosa yang disimpan dalam hati, otot adalah sumber utama energi. Setelah glukosa habis, maka lemak menjadi sumber energinya., ${ }^{2,7}$

Didapatkan hasil dari suatu penelitian yang mengkaitkan hubungan janin terhadap efek puasa tidak menimbulkan bayi menjadi bayi lahir rendah. Hal ini terkait dalam kondisi sang ibu yang berpuasa dan asupan makanan yang dibutuhkannya tercukupi. Kebanyakan dari mereka berpuasa saat trisemester pertama, kemungkinan hal ini terjadi karena mereka belum menyadari kehamilannya sehingga sebagian besar dari mereka tetap berpuasa, namun semakin berkurang yang berpuasa pada trisemester ketiga. ${ }^{8}$ 
Pada keadaan puasa, jangka waktu makan menjadi tidak sama dengan hari-hari di luar puasa Ramadhan. Waktu-waktu yang biasanya boleh sering makan menjadi harus tidak makan selama sekitar 13-14 jam (antara sahur dan buka). Tubuh beradaptasi pada keadaan ini melalui pengaturan neuroendokrin. Pada keadaan puasa kadar glukosa darah dipertahankan dalam batas fisiologis, karena glukosa sangat dibutuhkan tubuh sebagai satu-satunya sumber energi untuk otak dan eritrosit. Hormon yang berperan pada keadaan ini terutama adalah hormon glukagon yang dihasilkan oleh sel alfa pulau Langerhans pankreas. Hormon glukagon mempertahankan kadar glukosa darah melalui proses glikogenolisis dan glukoneogenesis. Sumber karbon untuk proses glukoneogenesis yaitu laktat, gliserol dan asam amino terutama alanin. Trigliserid jaringan adiposa merupakan sumber energi utama selama puasa Ramadhan. Trigliserid akan mengalami proses lipolisis menghasilkan gliserol dan asam lemak. Sebagian gliserol akan mengalami proses glukoneogenesis untuk mempertahankan kadar glukosa darah. Asam lemak akan mengalami oksidasi sebagai sumber energi. Sebagian asam lemak akan mengalami reesterifikafi membentuk trigliserid. ${ }^{7}$

Berikut adalah beberapa syarat makanan sehat bagi ibu hamil; menyediakan energi yang cukup (kalori) untuk kebutuhan kesehatan tubuh anda dan pertumbuhan bayi; menyediakan semua kebutuhan ibu dan bayi (meliputi protein, lemak, vitamin, mineral); dapat menghindarkan pengaruh negatif bagi bayi, dan mendukung metabolisme tubuh ibu dalam memelihara berat badan sehat, kadar gula darah, dan tekanan darah. ${ }^{9}$

\section{Kalori}

Seorang perempuan selama kehamilan memiliki kebutuhan energi yang meningkat. Energi ini digunakan untuk pertumbuhan janin, pembentukan plasenta, pembuluh darah, dan jaringan yang baru. Selain itu, tambahan kalori dibutuhkan sebagai tenaga untuk proses metabolisme jaringan baru. Tubuh memerlukan sekitar 80.000 tambahan kalori pada kehamilan. Dari jumlah tersebut, berarti setiap harinya sekitar 300 tambahan kalori dibutuhkan selama hamil. Memang cukup sulit untuk mengetahui berapa kalori yang telah dikonsumsi setiap harinya. Untuk jangka pendek kita dapat gunakan rasa lapar sebagai panduan kebutuhan kalori dan memonitor berat badan untuk membantu menilai banyaknya jumlah kalori yamg dikonsumsi. 8,9

\section{Protein}

Protein lebih banyak dibutuhkan selama kehamilan dibandingkan waktu-waktu lainnya. Hal ini dikarenakan protein diperlukan untuk pertumbuhan jaringan pada janin. Perempuan hamil membutuhkan sekitar 75 gram protein setiap harinya, lebih banyak 25 gram dibandingkan yang lain. Menambahkan protein ke dalam makanan merupakan cara yang efektif untuk menambah kalori sekaligus memenuhi kebutuhan protein. Produk hewan seperti daging, ikan, telur, susu, keju, dan hasil laut merupakan sumber protein. Selain itu protein juga bisa didapat dari tumbuh-tumbuhan seperti kacang-kacangan, biji-bijian, tempe, tahu, oncom, dan lainnya. ${ }^{9}$ 


\section{Asam Folat}

Folat merupakan vitamin B yang memegang peranan penting dalam perkembangan embrio. Folat juga membantu mencegah neural tube defect, yaitu cacat pada otak dan tulang belakang. Kekurangan folat juga dapat meningkatkan kehamilan kurang umur (prematur), bayi dengan berat badan lahir rendah (bayi berat lahir rendah/BBLR), dan pertumbuhan janin yang kurang. Asam folat sangat diperlukan terutama sebelum kehamilan dan pada awal kehamilan sekitar $600 \mathrm{mg}$ folat. Folat dapat didapatkan dari suplementasi asam folat. Sayuran berwarna hijau (seperti bayam, asparagus), jus jeruk, buncis, kacang-kacangan dan roti gandum merupakan sumber alami yang mengandung folat. ${ }^{9}$

\section{Zat Besi}

Zat besi dibutuhkan untuk memproduksi hemoglobin, yaitu protein di sel darah merah yang berperan membawa oksigen ke jaringan tubuh. Selama kehamilan, volume darah bertambah untuk menampung perubahan pada tubuh dan pasokan darah bayi. Hal ini menyebabkan kebutuhan zat besi bertambah sekitar dua kali lipat. Jika kebutuhan zat besi tidak tercukupi, perempuan hamil akan mudah lelah dan rentan infeksi. Risiko melahirkan bayi tidak cukup umur dan bayi dengan berat badan lahir rendah juga lebih tinggi. Kebutuhan zat besi yang dibutuhkan berkisar $27 \mathrm{mg}$ sehari. Selain dari suplemen, zat besi bisa didapatkan secara alami dari daging merah, ikan, unggas, sereal sarapan yang telah difortifikasi zat besi, dan kacang-kacangan. ${ }^{9}$

\section{Zat Seng (Zinc)}

Dari beberapa studi dilaporkan bahwa perempuan hamil yang memiliki kadar zat seng rendah dalam makanannya berisiko melahirkan prematur dan melahirkan bayi dengan berat lahir rendah. Sedangkan uji klinis suplementasi zat seng tidak didapatkan kejelasan mengenai keuntungan mengkonsumsi seng dalam jumlah yang lebih tinggi. Namun mengkonsumsi zat seng dalam jumlah cukup merupakan langkah antisipatif yang dapat dilakukan. Zat seng dapat ditemukan secara alami pada daging merah, gandum utuh, kacangkacangan, polong-polongan, dan beberapa sereal sarapan yang telah difortifikasi. Pada umumnya, perempuan tidak membutuhkan tambahan suplemen. Namun dapat mengkonsumsi suplemen (sekitar $25 \mathrm{mg}$ zat seng sehari) jika dalam kondisi yang kurang sehat. ${ }^{9}$

\section{Kalsium}

Janin mengumpulkan kalsium dari ibunya sekitar 25-30 mg sehari. Paling banyak ketika trimester ketiga kehamilan. Ibu dan bayinya membutuhkan kalsium untuk menguatkan tulang dan gigi. Selain itu, kalsium juga digunakan untuk membantu pembuluh darah berkontraksi dan berdilatasi, mengantarkan sinyal saraf, kontraksi otot, dan sekresi hormon. Jika kebutuhan kalsium tidak tercukupi dari makanan, kalsium yang dibutuhkan bayi akan diambil dari tulang ibu. Kebutuhan kalsium perempuan hamil adalah sekitar 1000 $\mathrm{mg}$ /hari. Sumber kalsium dari makanan diantaranya produk susu seperti susu, keju, yogurt. Selain itu ikan teri juga merupakan sumber kalsium yang baik. ${ }^{9}$ 


\section{Vitamin $C$}

Vitamin $\mathrm{C}$ yang dibutuhkan janin tergantung dari asupan makanan ibunya. Vitamin $\mathrm{C}$ merupakan antioksidan yang melindungi jaringan dari kerusakan dan dibutuhkan untuk membentuk kolagen dan menghantarkan sinyal kimia di otak. Wanita hamil setiap harinya disarankan mengkonsumsi 85 mg vitamin $\mathrm{C}$ /hari. Kita dapat dengan mudah mendapatkan vitamin $\mathrm{C}$ dari makanan seperti tomat, jeruk, strawberry, jambu biji, dan brokoli. Makanan yang kaya vitamin $\mathrm{C}$ juga membantu penyerapan zat besi dalam tubuh. ${ }^{9}$

\section{Vitamin A}

Vitamin A memegang peranan penting dalam fungsi tubuh, termasuk fungsi penglihatan, imunitas, serta pertumbuhan dan perkembangan embrio. Kekurangan vitamin A dapat mengakibatkan kelahiran prematur dan bayi berat lahir rendah. Vitamin A dapat ditemukan pada buah-buahan dan sayuran berwarna hijau atau kuning, mentega, susu, kuning telur, dan lainnya. ${ }^{9}$

\section{Hakekat Puasa dalam Kehamilan serta Hukumnya}

Kondisi fisik seorang perempuan dalam menghadapi kehamilan dan saat-saat menyusui memang berbedabeda. Namun, pada dasarnya kalori yang dibutuhkan untuk memberi asupan bagi sang buah hati adalah sama, yaitu sekitar 2200-2300 kalori perhari untuk perempuan hamil dan 2200-2600 kalori perhari untuk perempuan menyusui. Kondisi inilah yang menimbulkan konsekuensi yang berbeda bagi para perempuan dalam menghadapi saat-saat puasa di bulan Ramadhan. Ada yang merasa tidak bermasalah dengan keadaan fisik dirinya dan sang bayi sehingga dapat menjalani puasa dengan tenang. Ada pula perempuan yang memiliki kondisi fisik yang lemah yang mengkhawatirkan keadaan dirinya jika harus terus berpuasa di bulan Ramadhan begitu pula perempuan yang memiliki buah hati yang lemah kondisi fisiknya dan masih sangat tergantung pada sang ibu. Kedua kondisi terakhir, memiliki konsekuensi hukum yang berbeda. ${ }^{10}$

Perempuan hamil yang dianjurkan untuk tidak berpuasa yaitu saat:

1. Menurunnya tekanan darah,sampai yang bersangkutan pingsan, pusing, atau hilangnya konsentrasi

2. Muntah yang berkelanjutan, khususnya sampai $1 / 3$ awal dari masa kehamilan. Muntah tersebut menyebabkan hilangnya cairan dan garam mineral, seperti sodium dan potassium. Hal tersebut sangat berpengaruh pada pencernaan dan hilangnya nafsu makan

3. Meminum tablet yang dapat meningkatkan pembentukan kemih pada saat terjadi pembengkakan pada kedua kaki yang bukan disebabkan sebagai gejala keracunan kehamilan. Pada saat inilah tablet-tablet itu bekerja menghilangkan unsure potassium yang berbahaya bagi tubuh. Oleh karena itu, penting sekali bagi orang yang mengalami gangguan untuk tidak mengkonsumsi makanan yang kaya dengan usur potassium, seperti jeruk, pisang, dan tomatdiharapkan makanan itu dapat meringankan perasaan tertekan yang menimpanya, karena kurangnya kadar potassium dalam darah 
4. Terjadinya perdarahan yang dirasakan pada saat kehamilan, baik $1 / 3$ awal maupun $1 / 3$ akhir dari masa kehamilan

5. Penyakit yang dirasakan pada saat dalam kondisi hamil, terutama penyakit ginjal. Hal ini disebabkan karena pada saat seseorang menderita penyakit ginjal, maka akan terjadi pemusatan urine pada saat yang bersangkutan berpuasa dalam kondisi udara sangat panas. Ini akan berakibat fatal dan bebahaya pada penyakit ginjal yang dideritanya. Begitu pula penyakit jantung, penyakit diabetes yang tidak teratur, dan penyakit membesarnya kelenjar gondok yang juga sangat membahayakan

6. Keguguran yang terjadi berulang kali atau kelahiran prematur. Ada bukti-bukti ilmiah yang menunjukkan bahwa tidak mengkonsumsi makanan dalam jangka waktu yang lama dapat berakibat terjadinya keugurn atau kelainin premature

7. Mengalami keracunan yang ditunjukkan dengan meningkatnya tekanan darah dan bertambahnya berat badan yang disertai dengan pembengkakan pada kedua kaki. Hal itu sebagai akibat dari tertahannya cairan dan garam yang dibarengi dengan peningkatan kadar protein pada air seni. ${ }^{2}$

\section{Untuk Ibu Hamil dan Menyusui yang Mengkhawatirkan Keadaan Dirinya Saja Bila Berpuasa}

Bagi ibu, untuk keadaan ini maka wajib untuk mengqadha (tanpa fidyah) di hari yang lain ketika telah sanggup berpuasa. Keadaan ini disamakan dengan orang yang sedang sakit dan mengkhawatirkan keadaan dirinya. Sebagaimana dalam ayat: (Al-Baqarah (2):184)

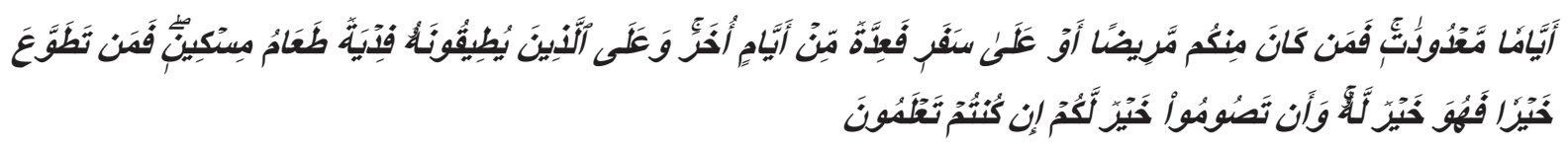

Yang Artinya : (yaitu) dalam beberapa hari yang tertentu. Maka barangsiapa diantara kamu ada yang sakit atau dalam perjalanan (lalu ia berbuka), maka (wajiblah baginya berpuasa) sebanyak hari yang ditinggalkan itu pada hari-hari yang lain. Dan wajib bagi orang-orang yang berat menjalankannya (jika mereka tidak berpuasa) membayar fidyah, (yaitu): memberi makan seorang miskin. Barangsiapa yang dengan kerelaan hati mengerjakan kebajikan, maka itulah yang lebih baik baginya. Dan berpuasa lebih baik bagimu jika kamu mengetahui 


\section{Untuk Ibu Hamil dan Menyusui yang Mengkhawatirkan Keadaan Dirinya dan Buah Hati Bila Berpuasa}

Sebagaimana keadaan pertama, sang ibu dalam keadaan ini wajib mengqadha (saja) sebanyak hari-hari puasa yang ditinggalkan ketika sang ibu telah sanggup melaksanakannya. ${ }^{10}$

Imam Nawawi rahimahullah mengatakan, "Para sahabat kami (ulama Syafi'iyah) mengatakan, 'Orang yang hamil dan menyusui, apabila keduanya khawatir dengan puasanya dapat membahayakan dirinya, maka dia berbuka dan mengqadha. Tidak ada fidyah karena dia seperti orang yang sakit dan semua ini tidak ada perselisihan (di antara Syafi'iyyah). Apabila orang yang hamil dan menyusui khawatir dengan puasanya akan membahayakan dirinya dan anaknya, maka sedemikian pula (hendaklah) dia berbuka dan mengqadha, tanpa ada perselisihan (di antara Syafi'iyyah).'” (al-Majmu': 6/177), dinukil dari majalah Al Furqon) ${ }^{10}$

Dalam keadaan ini, sebenarnya sang ibu mampu untuk berpuasa. Oleh karena itulah, kekhawatiran bahwa jika sang ibu berpuasa akan membahayakan si buah hati bukan berdasarkan perkiraan yang lemah. Dalil sang ibu wajib mengqadha adalah sebagaimana dalil pada kondisi pertama dan kedua, yaitu wajibnya bagi orang yang tidak berpuasa untuk mengqadha di hari lain ketika telah memiliki kemampuan. Para ulama berpendapat tetap wajibnya mengqadha puasa ini karena tidak ada dalam syari'at yang menggugurkan qadha bagi orang yang mampu mengerjakannya. Sedangkan dalil pembayaran fidyah adalah para ibu pada kondisi ketiga ini termasuk dalam keumuman ayat berikut,

“...Dan wajib bagi orang-orang yang berat menjalankannya (jika mereka tidak berpuasa) membayar fidyah, (yaitu) memberi makan seorang miskin..." (Qs. Al-Baqarah [2]:184). ${ }^{10}$

Walaupun telah diutarakan di atas mengenai seorang perempuan hamil yang tidak dianjurkan untuk berpuasa, hal ini seperti yang diutarakan oleh Ahli Obstetri dan Ginekologi sebenarnya di trimester berapa pun perempuan hamil boleh melakukan ibadah puasa selama. Lain halnya bila ada kondisi-kondisi penyulit yang menyertai kehamilan antara lain:

1. Perdarahan

Pada ibu yang pernah mengalami perdarahan semasa kehamilan, memaksakan diri hanya akan membuat keadaan kemungkinan bertambah parah. Paling tidak kalau tetap berpuasa, ibu tidak bisa mengonsumsi obat yang diresepkan.

2. Diabetes Melitus (DM)

Ibu hamil dengan DM tidak disarankan berpuasa. Pasalnya, selain harus menjalani terapi obat secara teratur, ibu hamil juga harus mematuhi program makan yang telah dibuatkan supaya kadar gula dalam darah bisa tetap terkontrol/bisa tetap stabil. 


\section{Hipertensi}

Mirip dengan DM, terapi obat tak boleh terlewatkan dalam kasus-kasus hipertensi. Bila terlewat, besar kemungkinan tekanan darah jadi tidak terkontrol, bisa naik atau turun. Padahal, tekanan darah yang naik turun seperti itu jelas-jelas harus dihindari selama hamil karena bisa menyebabkan kematian ibu maupun si bayi.

4. Anoreksia dan bulimia

Efek yang bisa terjadi adalah kekurangan cairan tubuh. Padahal cairan tubuh itu amat penting bagi si ibu hamil, terutama bayi yang sedang dikandung.

5. Gangguan sistem pencernaan

Salah satunya adalah gangguan mag. Ibu hamil dengan gangguan ini yang memaksakan diri berpuasa berarti memperbesar peluang penyakitnya akan kambuh. Lambung kosong akan mempertinggi peluang terjadinya peningkatan asam lambung.

6. Dehidrasi

Jika sampai mengalami hal ini, bisa dibayangkan apa jadinya si ibu hamil bersama bayi yang tengah dikandungnya. Karena itu jangan sungkan untuk lekas berbuka. Jangan sampai ibu hamil mengalami hal ini yang umumnya diawali dengan diare dan muntah berlebih, keringat dingin membanjir, disertai keluhan pusing dan lemas.

7. Hari $\mathrm{H}$ atau taksiran persalinan.

Di hari bersalin, ibu hamil tidak dianjurkan untuk menjalankan ibadah puasa. Soalnya ibu memerlukan energi ekstra untuk melahirkan si buah hati. Memaksakan diri untuk berpuasa hanya akan memperbesar peluang terjadinya hal-hal yang tidak diinginkan, seperti pingsan, persalinan "macet" lantaran tak ada energi, atau malah perdarahan hebat. ${ }^{11}$

Ada beberapa upaya yang dapat dilakukan jika seorang perempuan hamil ingin berpuasa, yaitu:

1. Minum sebelumnya. Alasan yang paling mungkin merasa kurang sehat saat berpuasa adalah dehidrasi. Pastikan untuk makan dengan baik dan minum banyak cairan sebelum matahari terbit. Protein dan lemak akan membuat tetap bersemangat.

2. Tetap tenang saat berpuasa.

3. Istirahat, untuk menghemat energi dan cairan, jika merasa pusing sebaiknya berbuka karena dapat membuat keadaan bayi tidak baik. 
4. Jika merasa pusing sebaiknya berbuka untuk minum cairan. Jika otak tidak mendapatkan cukup aliran darah dan oksigenmemungkinkan bayi keadaan tidak baik. Berbaring di tempat yang layak di manapun berada, jika merasa lemas, minumlah sampai merasa lebih baik. Jika air putih tidak bekerja, mungkin perlu sesuatu pengganti cairan yang terdapat asupan gizi yang cukup di dalamnya, seperti jus atau makanan.

5. Jika telah ada kontraksi rahim, harus minum beberapa cairan. Dehidrasi dapat menyebabkan kontraksi dan berpotensi persalinan prematur. Waktu yang paling sensitif dalam kehamilan pada trimester terakhir. Jika kontraksi tidak berhenti dengan istirahat dan cairan segera menghubungi dokter atau bidan atau pergi ke rumah sakit

6. Berbukalah segera dengan air secara perlahan-lahan. Makan makanan ringan yang mengandung Karbohidrat karena mudah dicerna, barulah makanan berlemak yang paling sulit untuk dicerna.

7. Dan yang paling penting: mendengarkan tubuh. Tubuhmu adalah barometer baik apa yang bayi lakukan. Jika merasa buruk, mungkin tidak baik bagi bayi. ${ }^{12}$

\section{KESIMPULAN}

Berpuasa salah satu ibadah yang identik dengan berpantang, terutama untuk berniat, berucap, dan atau melakukan perbuatan yang merupakan "pantangan" demi mencapai kesempurnaan akhlak, dimana sifat-sifat Allah menjadi terpresentasikan dalam diri manusia.

Kehamilan merupakan kondisi khusus yang hanya dihadapi oleh perempuan dan menjadi ujian yang sangat menegangkan bagi seorang perempuan. Banyak perubahan yang terjadi selama kehamilan berlangsung, baik dari psikis maupun fisik. Dalam Islam, perempuan yang tidak diharuskan berpuasa adalah; perempuan hamil dalam kelanjutan kehamilannya berbahaya bagi diri dan janinnya, mereka yang menyusui, mereka yang haid, dan perempuan yang berada dalam nifas.

Periode aman berpuasa bagi wanita hamil pada trisemester 1 dan 2 (di 4-6 bulan) dan kemudian tergantung pada kesehatan wanita hamil serta ada izin dan pengawasan dari dokter kandungan.

Kekurangan nutrisi dapat menyebabkan anemia, abortus, partus prematurus, inertia uteri, perdarahan pasca persalinan, sepsis puerperalis, dan lain-lain. Sedangkan makanan berlebihan, karena dianggap untuk 2 orang ibu dan janin, dapat menyebabkan komplikasi seperti gemuk, pre-eklamsi, janin besar, dan sebagainya. Zatzat yang diperlukan adalah protein, karbohidrat, zat lemak, mineral atau bermacam-macam garam; terutama kalsium, fosfor, dan zat besi (Fe); vitamin dan air.

Islam telah memberikan banyak kemudahan bagi ibu hamil dan menyusui karena kondisi mereka yang apabila berpuasa maka akan merugikan dirinya dan janin ataupun anaknya. Sehingga hukum yang mengatur akan hal tersebut tidak mewajibkan seorang ibu hamil dan menyusui untuk berpuasa dan menggantinya dengan berpuasa dihari lain ataupun membayar fidyah. 


\section{DAFTAR PUSTAKA}

1. Qauliyah, Asta. "Hakekat Puasa”. 23/11/2006. http://www.astaqauliyah.com/h11.html.

2. Thalbah, Hisham. "Ensiklopedia-Mukjizat Al-Qur'an dan Hadis, cetakan pertama, Jakarta, Sapta Sentosa, 2008.

3. Mochtar Rustam, MPH. Dr. Prof, “Sinopsis Obstetri”, Edisi kedua, EGC.

4. Irfan, Hwaa. "Fasting and Pragnancy". 10/27/2003. http://www.ramadanpregnancy.pdf/h4.html.

5. Info Bunda, "Sekilas Tentang Puasa dan Kehamilan”,05/09/2008. http://www.infobunda.com/h2.html.

6. Masroor, ajmal, "Ramadan Health and Spirituality Guide" CIA. http://www.RamadanHealthGuide. $\mathrm{pdf} / \mathrm{h} .30 . \mathrm{html}$

7. Meida, Shani, Nur. Pengaruh puasa Ramadhan pada ibu hamil, 10/01/2002. http://www.jurnal kedokteran yarsi.pdf.

8. Nasrollahi, Shahla. Interrelation of Ramadan Fasting and Birth Weight, 14:3, 91-95, 2001. http://www. Medical Journal of Islamic Academy of Sciences.pdf.

9. Sophia, Ennie. “Kebutuhan Gizi Ibu Hamil”. 20-05-2009, http://ramadanhealthguide.com/h4.html.

10. Ziyad, Ummu. “Antara Qadha dan Fidyah bagi Ibu Hamil dan Menyusui”. http://muslimah.com/h14. html.

11. Renny, “Ibu Hamil Bermasalah Disarankan tidak Berpuasa". http:/www.Indonesia ontime.humaniora. keshatan.com

12. Greenfield, Marjorie. Seven Guidelines for Religious Fasting in Pregnancy. 28/08/2008. http://www. Seven Guidelines for Religious Fasting in Pregnancy.html.

13. Sri Suhandjati Sukri, Ensiklopedi Islam Dan Perempuan, (Bandung: Penerbit Nuansa, 2009), 